\title{
Komunikasi Seni: Representasi Masyarakat Urban di Kota Bandung dalam Bingkai Karya Seni Karya Mufty Priyanka
}

\author{
Dedi Warsana $^{1}$, Salsa Solli Nafsika ${ }^{2}$, Nala Nandana Undiana ${ }^{3}$ \\ ${ }^{1,2,3}$ Program Studi Film dan Televisi Universitas Pendidikan Indonesia \\ Email: essa.navzka@upi.edu
}

\begin{abstract}
This study describes the communication of art through the culture of the people of Bandung in the frame of art creation focused on the phenomenon of the cosmopolitan city and then realizing the form of urban society with all forms of social phenomena in social life, especially in the Cicadas area, the social phenomena that emerge into its own dynamics that can be studied from various perspectives. In this study, researchers create a frame based on perceptions of social phenomena that occur in the midst of the dynamics of urban society. The method used is descriptive analysis which is qualitative in nature in describing perceptions related to special things from social phenomena that are found when observing works of illustration art that are closely related to the picture of urban society. This study describes the meanings of works of art created by artists, it is found that the works that appear are a form of representation of social phenomena as outlined in the form of works of art and indirectly. Thus, Mufty Priyanka's artwork becomes a communication medium for its creators to respond to various issues related to symptoms and social interactions that arise in densely populated areas, or areas that arise in the midst of the hustle and bustle of Bandung's urban society in perspective of arts.
\end{abstract}

Keywords: art communication, artwork, urban society

Abstrak: Penelitian ini mendeskripsikan komunikasi seni melalui budaya masyarakat Bandung dalam bingkai penciptaan seni terfokus pada fenomena kota kosmopolitan kemudian mewujudkan bentuk masyarakat urban dengan segala bentuk gejala sosialnya dalam kehidupan bermasyarakat, khususnya di daerah Cicadas, gejala sosial yang muncul menjadi dinamika tersendiri yang dapat dikaji dari berbagai perspektif. Dalam penelitian ini, peneliti membuat sebuah bingkai berdasarkan persepsi terhadap gejala sosial yang terjadi di tengah dinamika masyarakat urban. Metode yang digunakan adalah Analisis deskriptif bersifat kualitatif dalam menggambarkan persepsi terkait hal-hal istimewa dari gejala sosial yang ditemukan saat melakukan pengamatan pada karya seni ilustrasi yang erat kaitannya dengan gambaran masyarakat urban. Penelitian ini menjabarkan makna-makna dari karya seni yang diciptakan oleh seniman, ditemukan bahwa karya yang muncul merupakan wujud representasi gejala sosial yang dituangkan dalam bentuk karya seni dan secara tidak langsung maka pada karya seni Mufty Priyanka menjadi media komunikasi penciptanya merespon berbagai isu terkait gejala serta interaksi sosial yang muncul di kawasan padat penduduk, atau kawasan yang muncul di tengah hiruk pikuk masyarakat urban Bandung dalam perspektif seni.

Kata kunci: komunikasi seni, karya seni, masyarakat urban

\section{Pendahuluan}

Berbicara tentang peradaban manusia, tidak akan lepas dari persoalan seni dan budaya yang dihasilkan oleh manusia itu sendiri. Seni dan budaya merupakan dua hal yang selalu bersinggungan satu sama lain, tidak dapat dipisahkan, alasan ini yang menciptakan peradaban akan selalu hidup pada zamannya (Kamarusdiana, 2019). Karya seni tidak sebatas fenomena keindahan saja, tetapi sebuah ekspresi, tepatnya objektifikasi manusia pada ruang dan waktu ia berada (Supiarza, 2019). Pemahaman akan makna dari karya seni adalah upaya memproyeksikan kemampuan yang tersimpan dalam pengalaman seseorang atau sekelompok. Bentuk pemikiran lainnya dalam karya seni seharusnya dapat ditafsirkan karena merupakan 
ekspresi atau pengalaman hidup yang harus diisi dengan penafsiran yang halus dan mendalam (Inskip, MacFarlane \& Rafferty, 2008). Dalam konteks inilah mencari pemahaman sebagai upaya mendeskripsikan tindakan sosial yang bermakna serta memproyeksikan pemahaman tentang kehidupan manusia.

Kota Bandung dikenal dengan berbagai macam hal menarik yang terdapat di dalamnya. Gagasan kota kreatif saat ini melekat pada kota yang dikenal sebagai Paris Van Java (Kunto, 1985). Di luar bentuk kreativitas yang menjadi daya tarik Kota Bandung saat ini, ada banyak hal yang mungkin tidak diketahui khalayak luas. Padatnya ibu kota provinsi Jawa Barat ini menjadi daya tarik untuk pendatang. Laju urbanisasi sudah jelas terlihat sejak awal mula kota ini berkembang, ketika Bandung diawal terbentuknya sebagai kota menjadi pusat pertemuan dan hiburan, Kota Bandung telah memiliki daya tarik bagi masyarakat di luar Kota Bandung, sehingga Bandung berubah menjadi kota kosmopolitan (Kunto, 1985; Supiarza, 2019).

Bandung sebagai kota kosmopolitan kemudian mewujudkan bentuk masyarakat urban. Masyarakat perkotaan sering disebut juga urban community, pengertian masyarakat kota lebih ditekankan pada sifat-sifat kehidupannya serta ciri-ciri kehidupannya yang berbeda dengan masyarakat pedesaan (Muhammad, 2017). Faktor ekonomi merupakan salah satu persoalan bagi masyarakat urban, namun dibalik persoalan itu sifat konsumerisnya sangat tinggi. Sifat konsumeris merupakan ciri masyarakat urban, yakni belanja bukan karena kebutuhan, namun karena gengsi (Zahra, Mustaqimmah, \& Hendra, 2020). Masyarakat urban Kota Bandung, terutama kalangan bawah hidup di tempat yang padat penduduk. Fenomena kepadatan penduduk di Kota Bandung salah satunya dapat kita lihat di beberapa kawasan. Salah satu kawasan yang menjadi objek amatan peneliti adalah Cicadas, kawasan ini yang mulai berkembang pasca kemerdekaan Indonesia ketika menjadi salah satu pusat urban dan sentra ekonomi. Selain kawasan alun-alun di Kota Bandung. Di era tahun 1970-an hingga akhir 1990an, kawasan ini terkenal dengan pusat hiburan seperti bioskop dan tempat hiburan malam seperti billiard pool dan toko kaset. Df musisi besar seperti Deddy Stanzah, tokoh politik Mei Kartawinata hingga seniman dan budayawan Jeihan Sukmantoro dan Remy Sylado dikenal muncul dari kawasan Cicadas. Di tengah tingginya tuntutan dan gejala sosial yang terjadi di perkotaan, muncul persoalan baru di tengah kawasan yang awalnya menjadi pusat pertumbuhan perekonomian. Sebut saja ketimpangan yang muncul dari kesenjangan sosial hingga tingkat kriminal yang marak bermunculan. Tingginya persaingan akibat pertumbuhan ekonomi yang tergolong cepat juga memunculkan persoalan sulitnya memperoleh pemukiman yang layak akibat ketidak tersediaan lahan tempat tinggal. Tingkat kemiskinan yang meningkat juga mempengaruhi cara pandang masyarakat di kawasan tersebut akan pentingnya pemenuhan pendidikan yang layak (Jamaludin, 2015).

Dalam tulisannya yang berjudul "Untuk Apa Seni?", Bambang Sugiharto mengatakan bahwa seni merupakan hal yang sekilas tidak pokok, tidak penting, berlebihan, kegenitan, subjektif, dianggap sebagai suatu pemborosan demi tujuan yang tidak bisa dimengerti (Sugiharto, 2013).Tetapi disaat yang sama seni justru penentu segala bidang. Imajinasi kreatif, intuisi, emosi yang merupakan unsur-unsur pokok seni sesungguhnya menentukan dalam penelitian ilmiah. Pengertian lainnya tentang seni merupakan segala manifestasi batin dan pengalaman estetis dengan menggunakan media bidang, garis, warna, tekstur, volume, dan gelap terang (Redies, 2015). Mengacu kepada kata manifestasi, dapat dikatakan seni merupakan 
perwujudan dari perasaan atau pendapat yang dirasakan manusia sebagai respon terhadap pengalaman yang dialami. Kedua pengertian tersebut dapat disimpulkan bahwa seni secara tidak langsung menentukan fokus utama manusia dalam perkembangan budayanya.

Pengamatan karya seni yang dilakukan oleh peneliti menggunakan kerangka teori sosiologi seni sebagai landasan penciptaan. Hauser menyatakan secara sederhana sosiologi seni merupakan ilmu yang membuat analisa pada keterkaitan antara manusia dengan aktivitas seni (Mappalahere, 2018). Sosiologi seni mengkaji secara spesifik keterlibatan setiap individu manusia dengan aktivitas kesenian serta masyarakat lain di luar aktivitas seni. Fenomena budaya ini akhirnya mempengaruhi beragam aktivitas kesenian yang muncul di tengah masyarakat. Dalam konteks teori ini, masyarakat bertindak sebagai individu yang aktif, sehingga dapat dengan mudah memberikan penilaian atau respon pada aktivitas kesenian yang dirasakannya.

Bagaimana seni dalam sudut pandang masyarakat, seni merupakan sebuah media hiburan, yang dapat memberikan kebahagiaan bagi masyarakat (Turniadi, 2017). Secara tradisional, sikap kreatif seniman merupakan ancaman sosial, ideologis, politik bahkan ekonomis. Seni melalui sosiologi seni menjadi pembahasan yang sangat kompleks. Seniman sebagai pencipta seni, misalnya, menciptakan karya mungkin saja memiliki kaitan dengan latar belakang sosialnya, terkait golongan atau kelas tertentu, terpengaruh pengetahuan dan pengalaman pribadi, atau pun masyarakat tertentu. Dalam kaitan dengan karya seni, dapat dianalisa kemungkinan adanya pengaruh dari subjek atau pelaku tertentu yang mendominasi dalam proses penciptaan karya seni. Termasuk juga analisis kecenderungan pasar dan pengaruhnya karya-karya seni yang kemudian tercipta atau hadir.

Dalam proses pengamatan karya seni, peneliti berupaya membangun persepsi sosial dari lingkungan yang diangkat sebagai objek pengamatan. Persepsi sosial adalah proses menangkap arti objek-objek sosial dan kejadian-kejadian yang kita alami dalam lingkaran kita (Listyana, 2015). Manusia bersifat emosional, sehingga penilaian terhadap mereka bersifat berisiko (Mulyana, 2001). Mulyana mendefinisikan persepsi sebagai suatu proses internal yang memungkinkan kita untuk memilih, mengorganisasikan serta menafsirkan rangsangan dari lingkungan kita dan dari proses tersebut dapat mempengaruhi perilaku kita nantinya. Beberapa prinsip penting mengenai persepsi sosial dapat digunakan sebagai pembenaran atas perbedaan persepsi sosial. Persepsi manusia terhadap seseorang, objek, atau kejadian dan reaksi mereka terhadap hal-hal dapat berdasarkan pengalaman (dan pembelajaran) masa lalu mereka dengan orang, objek, atau kejadian serupa (Supiarza \& Sarbeni, 2021). Menurut pandangan konstruktivis, media karya yang dihasilkan dipandang bukan sebagai cerminan dari realita, tetapi juga sebagai hasil konstruksi dari perspektif peneliti (Darmawan, 2016). Dengan meneliti kehidupan masyarakat urban di Kota Bandung, maka akan terlihat konstruksi realitas dari pengamatan karya yang dilakukan oleh peneliti, serta isu-isu apa saja yang ditonjolkan dan disembunyikan, sehingga peneliti dapat membentuk persepsi dari interpretasi terhadap perspektif pada kehidupan masyarakat urban di Kota Bandung.

Persoalan identitas masyarakat urban yang dikaitkan dengan penciptaan karya seni dapat berdasar pada pandangan bahwa identitas kultural akan muncul dalam bentuk-bentuk spesifik yang menandakan keberadaannya. Karya yang muncul akan dianggap hadir ketika gejalagejalanya atau penampakannya berbeda dengan 'yang lain', mempunyai ciri yang khas dan 
khusus (Warsono, 2012). Tujuan mendasar dalam penelitian ini, yakni memberikan nilai edukasi tentang kelompok sosial dengan beberapa nilai dan norma yang disepakati bersama, gunanya adalah untuk mengatur status dan peranan manusia dalam struktur sosial. Nilai yang terkandung dalam sajian karya seni dua dimensi merupakan interpretasi sebuah kebiasaan yang didasarkan pada kode etik yang berlaku dalam masyarakat urban Kota Bandung. Nilai dan norma memberikan arahan kepada manusia mengenai apa yang benar dan salah, baik dan buruk, memberikan pedoman hidup untuk masa sekarang dan akan datang. Dimensi dari nilai adalah satuan interelasi dari beberapa nilai yang ada dalam sebuah kelompok masyarakat (Arkandito, Maryani, Rahmawan \& Wirakusumah, 2016).

Komunikasi Seni pada budaya masyarakat urban diartikan sebagai kegiatan komunikasi antar masyarakat yang memiliki latar belakang budaya yang berbeda pada satu kawasan perifer pada perfsektf penciptaan karya (Supiarza \& Sobarna, 2019). Pada dasarnya tidak ada manusia yang sama persis, masing-masing individu memiliki identitas, kebiasaan, budaya yang berbedabeda, termasuk cara pandang dan cara pikirnya terhadap suatu, hal itu tercermin pada sudut pandang para pelaku seni dengan keragaman sudut pandang melalui medium karya (Kusuma, 2016). Proses komunikasi seni antara seniman dengan penghayat akan selalu terjalin selama kehadiran karya seni masih dibutuhkan oleh manusia. Sebuah komunikasi seni selalu dilandasi dengan berbagai pengalaman dari kehidupan batin yang berbeda dan mampu menciptakan makna, bisa pula berupa 'pemaknaan baru' terhadap karya yang diapresiasi, yang juga tidak perlu serangam, namun tetap memberikan kemungkinan hadirnya suatu kepuasan pengalaman yang mendalam (Yunus, 2020; Supiarza \& Sobarna, 2019). Konstruksi seni dan komunikasi telah dikaitkan dalam berbagai cara oleh para peneliti dan cendekiawan secara lintas disiplin. Misalnya, filsuf John Dewey mengakar pengalaman estetika dalam hal interaksi dengan lingkungan, dengan alasan bahwa makna muncul melalui integrasi pengalaman baru dan lama; karya seni sebagai pendorong pembuatan makna menjadi instrumen komunikasi (Dewey, 1980). Sejarawan seni E. H. Gombrich, mengejar ide seni sebagai bahasa, beralasan bahwa seni tidak efisien sebagai komunikasi karena kurangnya terjemahan satu-ke-satu ekspresi seniman dan penerimaan penonton (Gombrich, 2000). Ramachandran dan Hirstein mengambil perspektif estetika berbasis ilmu saraf, berpendapat bahwa seniman menggunakan prinsipprinsip visual untuk menggairahkan sistem visual kita, dalam proses mengomunikasikan atau membangkitkan respons emosional pada pemirsa mereka (Ramachandran \& Hirstein, 1999). Penekanan biologis ini terkait dengan jalur pekerjaan lain tentang pentingnya perwujudan dalam memahami pengalaman estetika. Misalnya, Mark Johnson berpendapat bahwa kualitas makna yang berasal dari sebuah karya seni pada akhirnya didasarkan pada interaksi kita yang diwujudkan dengan lingkungan (bahkan jika pandangan komunikasi estetika yang berpusat pada bahasa menurunkan konstruksi makna dalam seni ke tingkat di bawah Bahasa) (Johnson, 2007).

Dalam komunikasi budaya/ seni dibutuhkan persepsi untuk melihat dan mendengar makna dalam karya seni tersebut. Penelitian mengenai pangrawit dan penonton berpendapat bahwa terdapat suatu komunikasi aksi dan reaksi dalam sebuah pertunjukan wayang, pangrawit adalah aksi dan penonton memberikan reaksi (Santosa, 2008). Dalam konteks komunikasi, seni rupa dapat dimaknai sebagai suatu proses aksi dan reaksi antara lukisan dan masyarakat yang melihat lukisan itu. Praktik penulisan seni rupa dalam media massa merupakan salah satu faktor 
penting dalam mendongkrak kemajuan kesenirupaan hingga saat ini (Undiana, 2018). Selain film, seni rupa juga merupakan media berbasis identitas masyarakat (Undiana, Sarbeni, Ardiansyah, \& Razan, 2020).

Hal lain mengenai ruang lingkup masyarakat mencerminkan tata budaya manusia yang ada di dalamnya. Kebiasaan sebagai budaya sosial tidak hanya sekedar tercermin pada perilaku, namun diperkuat dengan dampak kondisi kebiasaan masyarakat itu sendiri, kebiasaan masyarakat juga berperan pada pembentukan ruang-ruang sosial dan simbolik (Rengganis \& Tjahjodiningrat, 2021). Hubungan manusia dengan budaya adalah bagaimana suatu budaya dari daerah tertentu dicirikan melalui kebiasaan dan dampak dari kebiasaan tersebut dalam lingkup masyarakat. Hal itu tercermin pada penelitian komunikasi seni pada budaya masyarakat oleh Oki Cahyo Nugroho pada simbol masyarakat berupa bentuk karya seni tiga dimensi di Ponorogo (Nugroho, 2016). Landasan fundamental pada penelitian mengungkap perspektif seniman mersepon kebudayaan sebagai suatu kebiasaan dalam kehidupan suatu masyarakat, dalam konteks komunikasi seni. Seniman berupaya untuk menyampaikan pesan sebagai representasi ide dan gagasan empiris yang dituangkan dalam bentuk gambar. Penelitian ini mencoba untuk menyelami bagaimana representasi masyarakat urban diwujudkan dalam bentuk lukisan atau ilustrasi dua dimensi sebagai media komunikasi seni merespon budaya masyarakat Cicadas, dan karya tersebut mampu dimaknai sebagai upaya seniman memotret realitas masyarakat urban di Kota Bandung.

\section{Metode}

Penelitian ini menggunakan metode deskriptif kualitatif, di mana digunakan juga teknik triangulasi untuk mendapatkan informasi yang mendalam. Selain itu, penelitian ini juga memberikan tafsir terhadap teks gambar sebagai sebuah media komunikasi seniman untuk menampilkan realitas masyarakat urban, yaitu masyarakat Cicadas Kota Bandung. Tafsir ini dibutuhkan untuk mengonfirmasikan dari data-data yang lain.

Sumber data didapatkan dari informan utama, yaitu Mufty Prianka, seorang seniman muda Kota Bandung yang menjadikan daerah Cicadas sebagai objek karyanya dan menjadi topik analisis. Penulis melakukan dialog atau wawancara langsung dengan seniman dan masyrakat untuk memperoleh data penelitian serta dalam teknik pengumpulan data penulis melalukan pengamatan lagsung guna mendapatkan visualisasi yang akurat terkait fenomena yang terjadi pada masyrakat urban di daerah Cicadas, lalu data yang diperoleh diolah dengan menggunakan pendekatan analisis deskriptif bersifat kualitatif, artinya dalam pendalaman kajian hasil dari narasumber (seniman atau masyarakat) dengan temuan langsung di lapangan dan menggali kebenaran konsep bentuk karya mengenai informasi tertentu dengan menggunakan berbagai sumber data seperti dokumen, arsip, hasil wawancara, hasil observasi atau juga dengan mewawancarai lebih dari satu subjek yang dianggap memiliki sudut pandang yang berbeda sebagai pola dalam analisis data.

Dalam pengumpulan data, beberapa tahapan penelitian dilakukan, seperti observasi wilayah Cicadas dengan panduan karya Mufty Prianka, wawancara pada masyarakat Cicadas yang mewakili cerita gambar, pendokumentasian tempat-tempat yang mewakili masyarakat urban Cicadas dan studi literatur terhadap jurnal, buku, majalah, koran dan lain-lain yang menuliskan tentang wilayah Cicadas. Setelah seluruh data didapatkan, peneliti melakukan 
coding dan memilah data-data primer dan sekunder untuk mendapatkan substansi penelitian kemudian dilanjutkan dengan proses analisis data untuk menjawab rumusan masalah penelitian ini.

\section{Hasil dan Pembahasan}

Dalam proses penciptaan, perlu dibuat sebuah alur pendukung berdasarkan pengamatan terhadap subjek utama gagasan karya. Dalam penelitian ini, peneliti menjabarkan dalam beberapa poin penting terkait gejala sosial yang muncul di kawasan padat penduduk yaitu Cicadas Kota Bandung. Gejala sosial yang muncul memungkinkan timbulnya gesekan pada individu maupun kelompok tertentu. Dalam penelitian ini, praktik premanisme menjadi salah satu fenomena yang akan peneliti angkat. Namun lebih jauh, peneliti mencoba melihat praktikpraktik premanisme tersebut dari berbagai sudut pandang, dengan bingkai penciptaan karya seni rupa, penulis membuat sebuah pandangan tersendiri terkait praktik yang selama ini dianggap kebanyakan orang selalu bersifat negatif.

Fenomena sosial terdiri dari proses perilaku yang ada dilakukan oleh manusia. Proses manusia ini mencakup aspek perilaku dan pengalaman yang dapat diakses melalui pemeriksaan simbol linguistik dan humanistik. Tapi, apakah fenomena sosial itu? Orang bisa menyebut ini sebagai interaksi antara manusia, termasuk perilaku mereka yang memengaruhi interaksi yang sama ini. Tentu saja interaksi ini juga dapat mencakup pengaruh dari perilaku historis atau masa lalu. Menurut epistemologi, yang merupakan cabang filosofis yang melihat ke dalam hakikat dan batas-batas pengetahuan manusia, pengetahuan juga merupakan fenomena sosial yang disebarkan dari satu individu ke individu lainnya.

Pada penelitian ini, peneliti mencoba melihat bagaimana cara kerja Mufti Priyanka menggambarkan fenomena sosial dalam bentuk interaksi yang terjadi dimasyarakat perkotaan di Cicadas. Daerah tersebut merupakan salah satu kelurahan dari enam kelurahan di Kecamatan Cibeunying Kidul Kota Bandung,

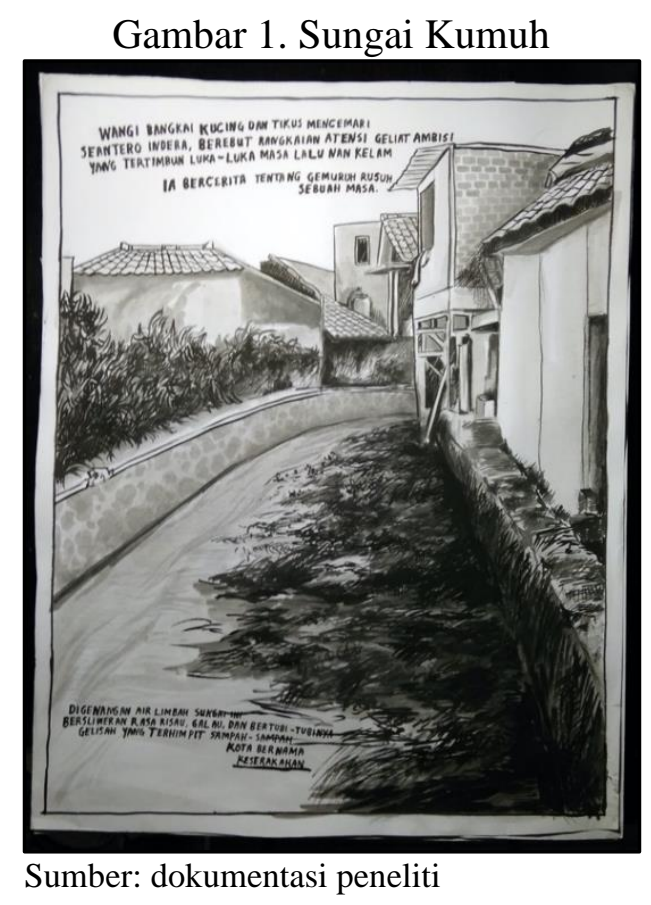


Lingkungan di kawasan Cicadas yang merupakan kawasan padat penduduk tercermin dalam tampilan karya "Sungai Kumuh". Tahapan awal dalam proses pengamatan yang dilakukan oleh peneliti adalah peristiwa pendangkalan sungai akibat musim panas yang terjadi saat proses pengamatan berlangsung. Namun fenomena pendangkalan sungai yang tampak di kawasan Cicadas merupakan akibat dari penumpukan sampah domestik. Hal tersebut membuat kondisi sungai tampak lebih kumuh ketika seluruh sampah domestik tersebut muncul ke permukaan.

Komposisi dari kesatuan objek dalam pengamatan peneliti menjadi salah satu gagasan yang memunculkan pengalaman estetik. Suasana dari lanskap yang digambarkan secara vertikal dengan posisi portrait, bertolak belakang dengan kebiasaan penggambaran lanskap pada umumnya (dengan posisi horizontal). Hal ini merupakan bentuk novelty dari karya yang ingin disampaikan oleh peneliti. Dengan kata lain, peneliti mencoba memberikan gambaran baru yang dapat diapresiasi diluar kebiasaan pola penggambaran lanskap pada umum. "Ia bercerita tentang gemuruh rusuh sebuah masa", merupakan potongan teks yang menganalogikan sebuah zaman yang menggambarkan ingatan peneliti. Pengalaman peneliti terkait kawasan Cicadas mengantarkan sebuah ingatan terkait keinginan untuk mendengar kabar baik. "Wangi bangkai kucing dan tikus...." juga merepresentasikan kejadian yang kurang baik untuk diingat. Dalam konteks ini, ada upaya mengajak penikmat karyanya untuk membayangkan kawasan Cicadas secara subjektif berdasarkan gambaran karya tersebut.

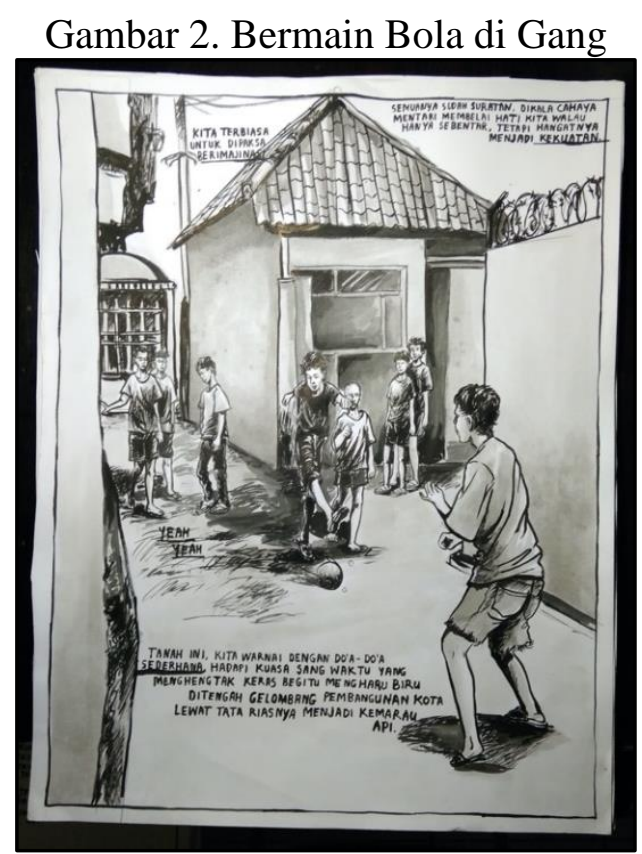

Sumber: dokumentasi peneliti

"Tanah ini, kita warnai dengan doa-doa sederhana. Hadapi kuasa sang waktu yang menghentak keras begitu mengharu biru ditengah gelombang pembangunan kota lewat tata riasnya menjadi kemarau api." Teks dalam karya "Bermain Bola di Gang" dapat dianalogikan sebagai gambaran dari kepadatan penduduk di kawasan Cicadas. Pemanfaatan lahan yang tidak sesuai dengan peruntukannya menjadi hal yang kerap kali ditemui selama pengamatan. Sudutsudut gang yang padat berubah menjadi arena bermain anak-anak. Kehidupan kota yang serba 
berkecukupan masih menjadi mimpi sebagian besar warganya, sementara mimpi untuk hidup layak masih jauh jika dilihat dari kondisi yang diamati oleh peneliti.

Kondisi kekumuhan, terlihat dari bangunan yang berhimpitan, ukurannya kecil, kondisi bangunan tidak memadai seperti dinding rumah yang kusam dan kotor, pentilasi rumah tidak ada, atap dari seng atau genteng yang sudah tua, jika hujan terjadi bocor. Keadaan rumah pengap, lembab dan gelap. Permukiman kumuh terletak di gang-gang sempit. Tidak ada sarana ruang terbuka bagi anak-anak untuk bermain. Setiap rumah tidak terdapat pembagian ruang seperti ruang tamu, dapur atau kamar tidur. Seringkali untuk sarana memasak dilakukan di depan rumah dengan menyimpan kompor dan ditutupi triplek seadanya. Sarana untuk menjemur pakaianpun dilakukan di depan rumah. Hal ini menambah kesemrawutan dan ketidak-teraturan lingkungan sekitar permukiman kumuh. Kondisi ini terdapat hampir disemua RW yang kondisinya kumuh.

Peneliti mencoba mendramatisir suasana dalam karyanya dengan menggunakan teks yang berupaya menjabarkan kondisi amatannya secara metafor. Berangkat dari gagasan untuk mengingatkan pentingnya ruang publik, mencoba memberikan representasi harapan dari setiap warga di kawasan Cicadas. Di sisi lain, perkembangan kota yang terus melaju dengan pesat, sedikit demi sedikit mengambil mimpi dari kebanyakan warga kawasan Cicadas untuk memenuhi kebutuhan ruang publiknya.

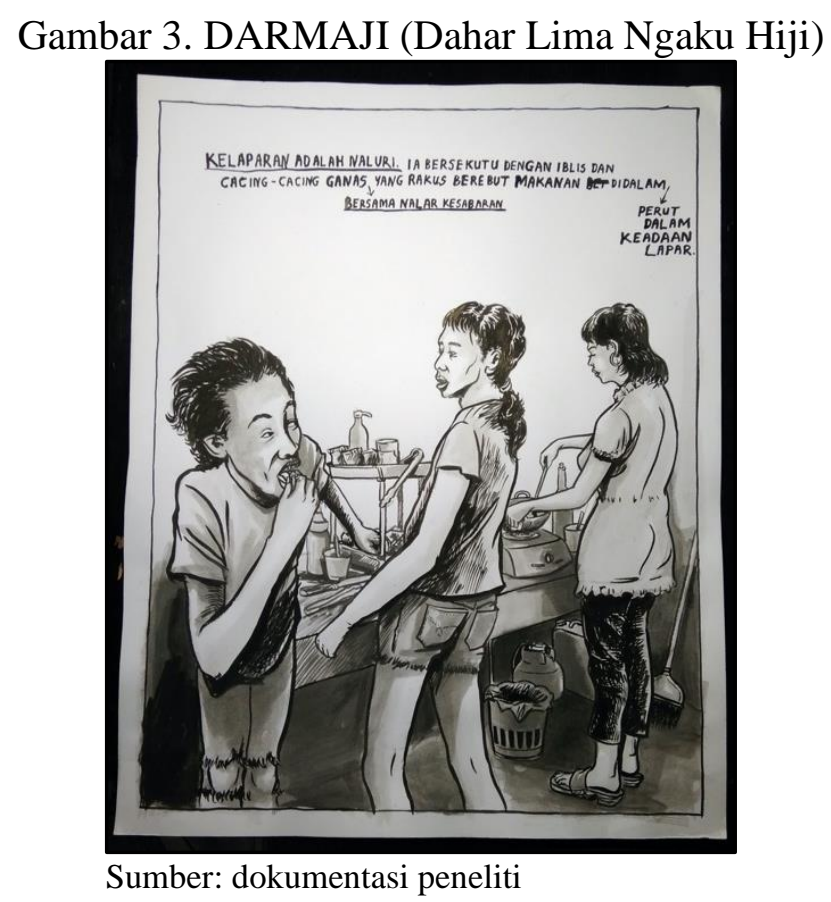

Dahar Lima Ngaku Hiji atau DARMAJI (memakan lima mengaku satu) merupakan ungkapan musiman yang dituturkan oleh kelompok sosial tertentu dalam situasi informal. Istilah tersebut merujuk pada perilaku seseorang yang secara tidak jujur dalam melakukan transaksi ekonomi mikro. Stigma masyarakat terhadap kawasan padat penduduk selalu mengarah pada krisis perekonomian yang rendah. Pola ini mengakibatkan banyak hal termasuk kelaparan, putus sekolah dan berbagai bentuk ketimpangan ekonomi ditingkat mikro. 
Himpitan kondisi ekonomi yang tergambar dari pengamatan peneliti selama berada di kawasan Cicadas menunjukan kemampuan beberapa individu untuk 'mengakali' banyak hal. Dalam ilutrasi karya DARMAJI, Mufty Priyanka menggambarkan kemampuan individu untuk mencari jalan keluar dari persoalan dalam proses pemenuhan kebutuhan dasar untuk bertahan hidup.

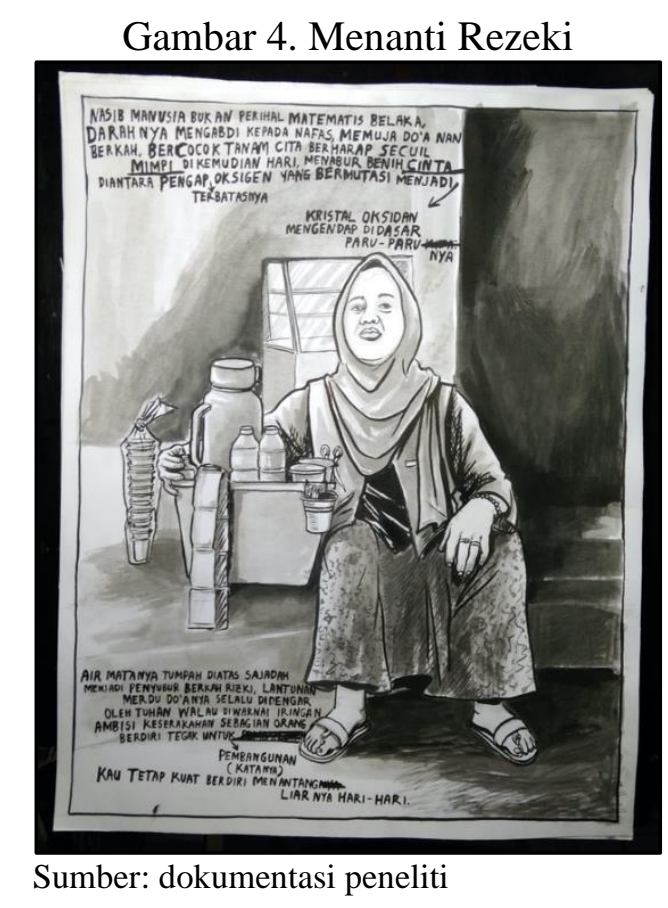

Kreativitas dalam proses memenuhi kebutuhan sehari-hari merupakan upaya yang ditempuh oleh setiap warga di kawasan yang diamati. Usaha Mikro Kecil dan Menengah (UMKM), aktivitas ini merupakan satu model dalam kegiatan perniagaan atau perdagangan yang muncul secara kreatif dalam berbagai keterbatasannya. Kebutuhan akan lapangan pekerjaan disimulasikan dalam bentuk karya "Menanti Rezeki". Beberapa kalimat seperti "Kristal oksidan mengendap di paru-parunya" merupakan metafor dari ketidakadilan yang diamati oleh peneliti. Beban kerja yang terus meningkat pada praktiknya tidak memberikan penghidupan yang layak bagi sebagian orang. Tumbuhnya kawasan permukiman dalam sebuah kota akan berpengaruh pada peningkatan aktivitas sosial yang terjadi di dalamnya pula. Berangkat dari kepadatan penduduk yang terdapat di Kawasan Cicadas, Kota Bandung, beberapa jenis pekerjaan yang kerap kali tampak dalam lingkungan padat penduduk, di antaranya; pedagang asongan, buruh lepas, buruh pabrik, tukang becak, supir angkutan umum, pengamen dan sektor informal skala kecil. Situasi tersebut menggambarkan terjadinya kelebihan tenaga kerja di perkotaan. Meskipun demikian, aktivitas ekonomi yang terjadi dapat dikatakan memberikan imbalan yang rendah bagi pelakunya (Gilbert \& Gugler, 1996). Upaya untuk memenuhi kebutuhan sehari-hari menuntut seseorang untuk mencari celah dalam melakukan usaha yang gigih. Terdapat sosok ibu yang dicitrakan sebagai mahluk mulia yang melakukan berbagai upaya untuk memenuhi kebutuhan hidupnya. Representasi kehidupan di kawasan padat penduduk yang digambarkan dalam karya ini merujuk pada peliknya kehidupan ditengah himpitan kebutuhan ekonomi. Melihat suatu kenyataan, di mana tidak dapat dipungkiri 
bahwa usaha-usaha pembangunan yang selama ini digalakkan pemerintah tidak banyak membawa hasil pada kehidupan masyarakat. Pembangunan yang selama ini dititik-beratkan pada sektor formal seperti perancanangan industrialisasi di suatu wilayah, berdampak pada ketimpangan pembangunan dalam berbagai bidang kehidupan, seperti bidang ekonomi.

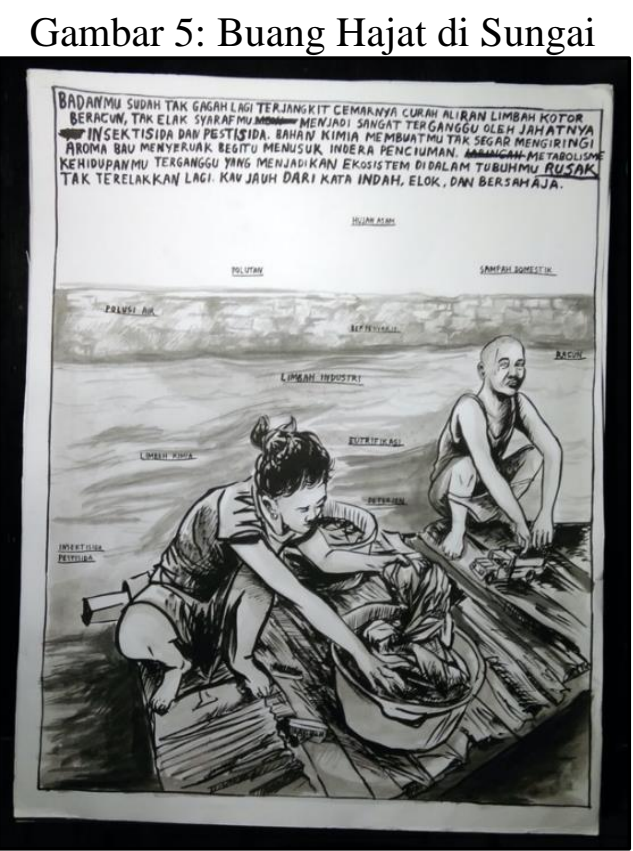

Sumber: dokumentasi peneliti

Sampai saat ini masalah kependudukan di Indonesia masih belum dapat diatasi secara maksimal dan optimal. Permasalahan kependudukan ini dikarenakan jumlah penduduk yang besar diikuti dengan pertumbuhan penduduk yang tinggi. Dengan bertambahnya jumlah penduduk tersebut berarti pula bertambahnya jumlah tempat untuk bermukim. Karena pertumbuhan tempat bermukim yang sangat pesat sedang luasan lahan yang terbatas, maka menyebabkan tumbuhnya permukiman padat di pusat kota. Disamping itu kurangnya ketersediaan ruang tersebut berakibat pada pertumbuhan kawasan permukiman yang tidak tertata dan tidak terkendali yang mengakibatkan terjadinya kondisi kumuh pada kawasan permukiman itu sendiri. Hal tersebut yang diamati oleh peneliti ketika melihat perubahan fisik sungai yang rusak oleh kebutuhan penduduk Kawasan Cicadas. Walaupun kondisi yang tergambar dalam ilustrasi saat ini sudah jarang ditemui, namun terdapat analogi penggambaran pola-pola perilaku yang mencemari lingkungan sungai. 


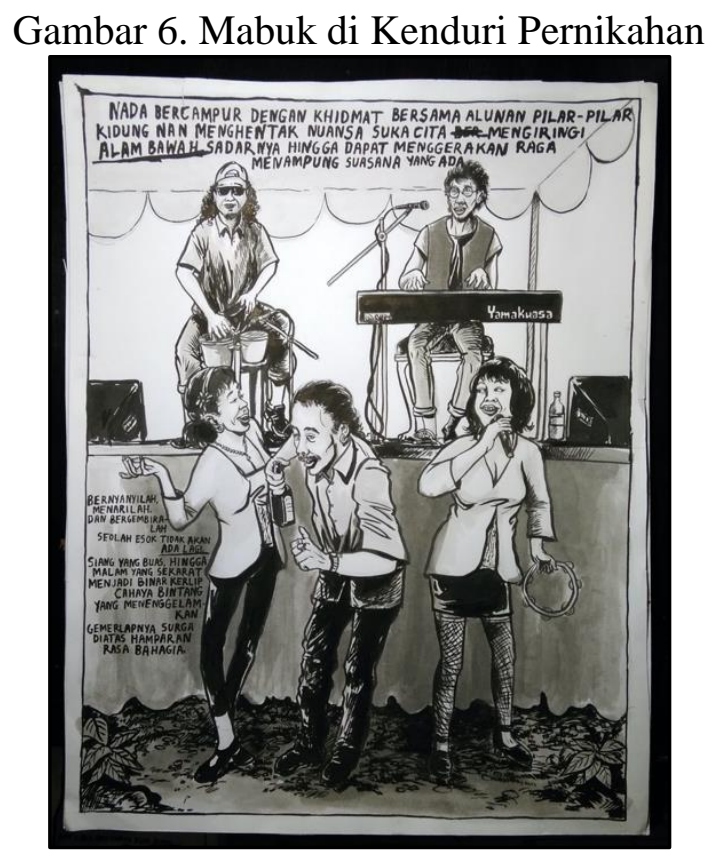

Sumber: dokumentasi peneliti

Hiburan merupakan pemenuhan kebutuhan sekunder yang tidak seimbang dengan pemenuhan kebutuhan primer. Gejala ini masuk ke dalam perubahan gaya hidup pada masyarakat urban. Suatu gejala yang akan selalu ada dalam masyarakat, karena masyarakat selalu berubah dalam aspek terkecil sekalipun. Perubahan sosial maupun perubahan budaya sebenarnya dua konsep yang berbeda tetapi saling berkaitan satu sama lain, dimana perubahan sosial mengacu pada perubahan struktur sosial dan hubungan sosial di masyarakat sedangkan perubahan budaya mengacu pada perubahan segi budaya di masyarakat.

"Mabuk di Kenduri Pernikahan" merupakan bentuk analogi yang ditunjukan oleh peneliti untuk perubahan gaya hidup masyarakat urban. Hal ini dianggap berkaitan erat dengan objek amatan penelitian. Penggambaran sosok seorang pemuda yang sedang mabuk di antara biduan yang sedang menghibur suatu acara pernikahan, menjadi gambaran pemenuhan kebutuhan akan hiburan bagi sebagian orang. Di sisi lain, beberapa individu dapat dengan mudah mengatur jadwal pemenuhan kebutuhan hiburannya, namun di lain sisi ada beberapa golongan masyarakat yang memanfaatkan momen-momen tertentu untuk mememuni kebutuhannya akan hiburan, walaupun tidak jarang situasinya kurang tepat. 


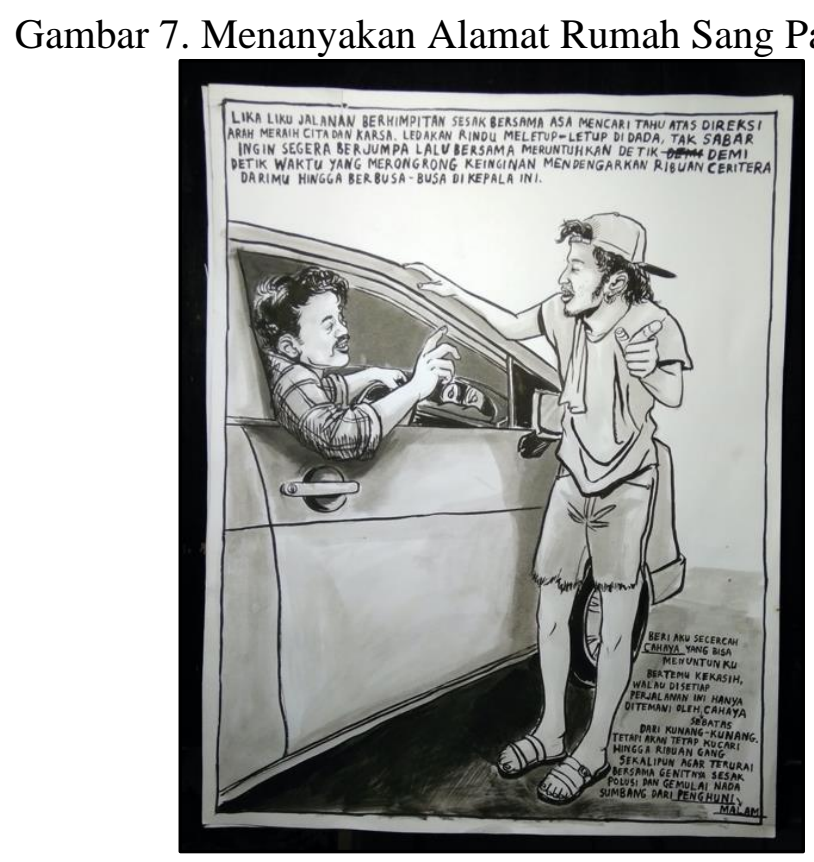

Sumber: dokumentasi peneliti

Dalam fenomena sosial dan budaya di dalam sebuah kelompok masyarakat, kita dapat melihat cara pandang yang berbeda dari beragam sudut pandang. Hasil pengamatan yang dilakukan oleh peneliti pada kawasan Cicadas memperlihatkan bentuk representasi kesenjangan sosial-ekonomi antara masyarakat pesisir (kawasan padat penduduk) dengan perkotaan dalam lima aspek, yaitu aspek ekonomi, aspek pendidikan, aspek lingkungan, aspek sosial dan aspek budaya. Berangkat dari lima aspek tersebut, ditemukan dikotomi bahwa masyarakat pesisir direpresentasikan sebagai masyarakat yang miskin, bodoh, kotor, terhina dan orang bawahan, sedangkan masyarakat perkotaan direpresentasikan sebagai bangsawan, pintar, kaya, terhormat, bersih, dan orang atasan. Kompleksnya permasalahan yang ada dalam kawasan padat penduduk menunjukan berbagai gejala yang pada dasarnya tidak sesuai dengan semestinya. Pada dasarnya, interaksi memiliki peran kunci dari semua kehidupan sosial, tanpa adanya interaksi, tidak mungkin ada kehidupan bersama. Namun di luar interaksi yang terlampau berlebih juga akan menimbulkan gesekan-gesekan baru yang memicu berbagai persoalan dalam kehidupan sosial, salah satunya adalah persoalan ekonomi.

Dikotomi terkait representasi kesenjangan tersebut digambarkan dalam karya "Menanyakan Alamat Rumah Sang Pacar Baru". Perbedaan cara pandang dari sebuah pola komunikasi yang terjalin antara masyarakat penghuni kawasan Cicadas dengan pendatang (orang yang tidak tinggal di kawasan tersebut) menjadi materi utama yang di citrakan oleh peneliti dalam karya ini. 


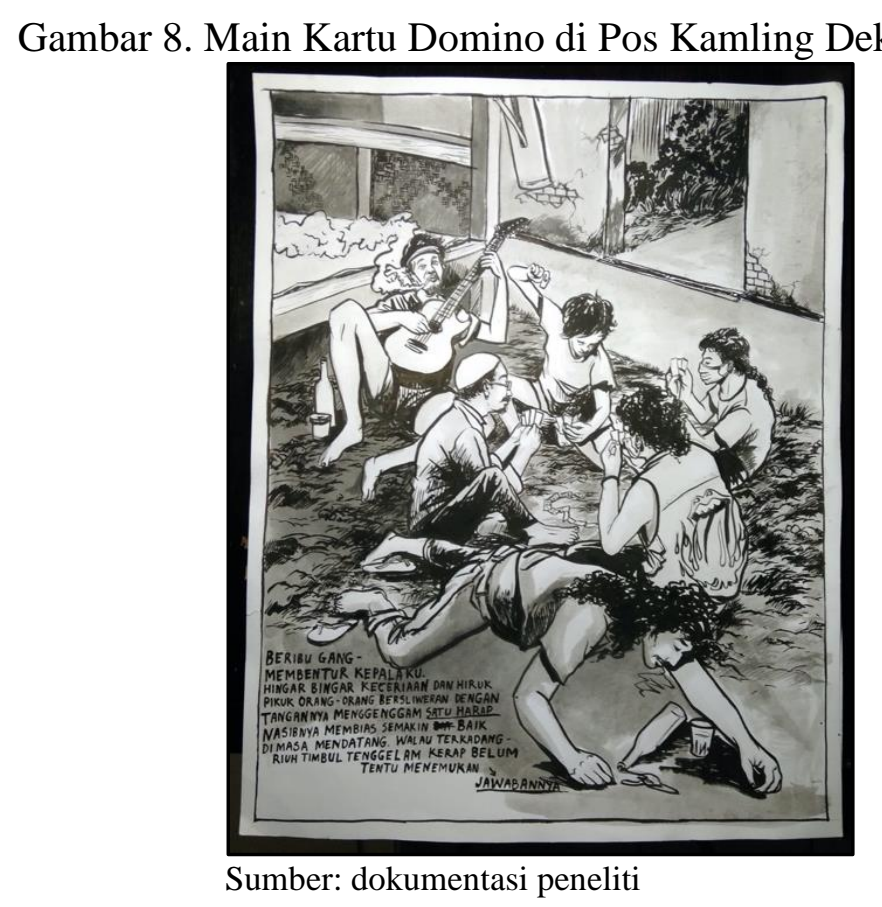

Kultur pemahaman dan pemaknaan arti serta fungsi ruang publik suatu kota bisa berubah karena perubahan tata nilai dan pemaknaan tempat yang bersangkutan. Pemahaman tentang fungsi ruang publik merupakan upaya kreatif yang dilakukan oleh peneliti dalam melihat kultur dan struktur sosial pada kawasan Cicadas yang memiliki luas wilayah sebesar 55 ha dengan ketinggian 700 meter dari permukaan laut dan termasuk daerah dataran. Berdasarkan data yang diperoleh dari hasil sensus Badan Pusat Statistik Kota Bandung. Kelurahan Cicadas secara keseluruhan merupakan area permukiman, dari luas wilayah 55 ha, sebanyak 20 ha merupakan area permukiman milik Angkatan Darat (PPI) yang berlokasi di RW 13. Sisanya merupakan area permukiman penduduk biasa. Jumlah penduduk di RW 13 yang merupakan kompleks perumahan Angkatan Darat berdasarkan laporan kependudukan tahun 20017 adalah sebanyak 2027 jiwa atau 15,73 \% dari keseluruhan jumlah penduduk di Kelurahan Cicadas. Kelurahan Cicadas termasuk kelurahan yang sangat padat, karena kondisi warganya yang masuk kedalam ekonomi menengah ke bawah serta bekerja disektor informal, seperti kuli bangunan, tukang becak, tukang sumur, pedagang. Hal tersebut membuat banyak daerah di Kawasan Cicadas tampak kumuh, rumahnya rata-rata kecil kurang lebih ukuran 2 x 4 m, anggota keluarga banyak antara 5 orang lebih malah sampai 10 atau 12 orang dalam satu rumah. Ciri-ciri suatu daerah kumuh adalah lingkungan kotor, rumahnya kondisinya tidak layak huni, tidak ada ventilasi, sempit, tidak ada pembagian ruang seperti memasak, tidur, ruang tamu (ruangannya bersatu).

"Beribu gang membentur kepalaku. Hingar bingar keceriaan dan hiruk pikuk orang-orang berseliweran....", merupakan analogi yang digambarkan tentang mobilitas yang muncul dari kawasan padat penduduk. Ruang-ruang sempit yang tersedia dimanfaatkan dengan sangat maksimal, sehingga tidak menyisakan ruang-ruang yang dapat berfungsi sebagai ruang publik. Dampak pertumbuhan penduduk yang cukup pesat juga berkaitan erat dengan masalah ruang yang terdapat pada lokasi permukiman. Fenomena ini tampak jelas di Kawasan Cicadas, Kota Bandung, di mana penduduknya dapat dengan leluasa menciptakan ruang-ruang sendiri bersama dengan memanfaatkan tempat-tempat tertentu. Hal ini tidak hanya dilakukan guna 
memenuhi kebutuhan tempat tinggal, pada akhirnya masyarakat juga menggunakan ruang publik yang seharusnya digunakan bersama menjadi ruang privat yang memiliki fungsi sebagai pemenuhan kebutuhan ekonomi. Walaupun disediakan ruang publik, kadang kala masyarakat kurang dapat memanfaatkannya, sehingga banyak kehidupan sosial yang terjadi di dalam setingan ruang-ruang terbuka publik (public open space setting) yang mulanya dirancang sebagai fungsi lain

Pergeseran fungsi ruang publik juga muncul dari kebutuhan akan ruang-ruang dalam proses pemenuhan kebutuhan. Dalam proses pengamatannya, peneliti banyak melihat berdiri Pos Kamling (Pos Keamanan Lingkungan) dihampir tiap wilayah Rukun Warga Cicadas. Peran pos keamanan tersebut adalah menjadi menara pantau untuk keamanan di lingkungan sekitar, hal tersebut berkaitan erat dengan bentuk-bentuk aktivitas penjagaan keamanan lingkungan. Kawasan padat penduduk memang erat kaitannya dengan tindak kriminal, sehingga tidak jarang jika masyarakatnya memilih untuk secara gotong-royong ikut serta menjaga ketertiban serta keamanan lingkungan. Alih-alih menjadi pusat penjagaan keamanan lingkungan, pos kamling yang berdiri di kawasan Cicadas kerap kali menjadi lokasi berkumpul pemuda sekitar. Dengan dalih menjaga keamanan lingkungan, tidak jarang kumpulan pemuda tersebut menjadi awal dari persoalan baru yang merujuk pada tindakan yang kurang sesuai di lingkungan masyarakat.

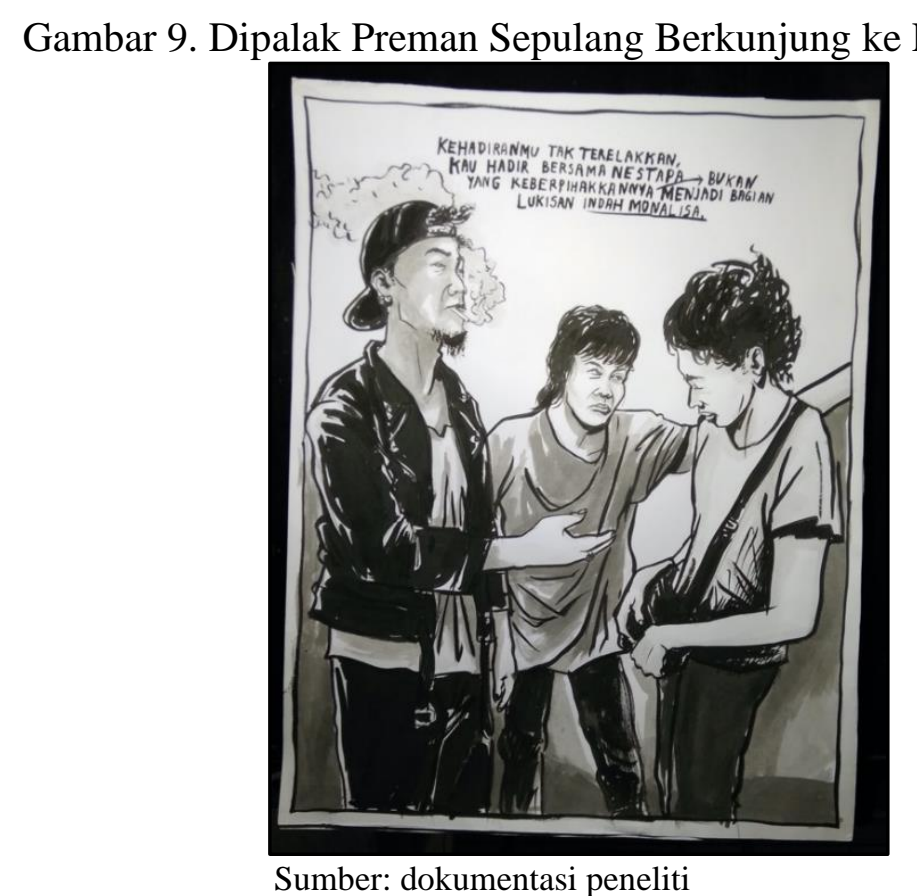

"Kehadiranmu tak terelakan, kau hadir bersama nestapa yang keberpihakannya bukan menjadi bagian lukisan indah Monalisa", kata nestapa dalam karya "Dipalak Preman Sepulang Berkunjung ke Rumah Pacar" merupakan analogi yang digambarkan oleh peneliti tentang kesedihan di tengah himpitan pergeseran budaya. Praktik premanisme yang muncul di kawasan padat penduduk seperti Cicadas bukan hanya berangkat dari kebutuhan material semata. Ada hierarki sosial yang muncul secara kasat mata dalam upaya menunjukan eksistensi masyarakat lokal. Penggambaran kesenjangan sosial sebagai penyebab adanya banyak masalah sosial. Studi-studi komprehensif ekonomi utama dalam kehidupan bermasyarakat bahkan 
mengungkapkan adanya hubungan antara ketimpangan sosial seperti masalah premanisme yang dianggap sebagai masalah alami yang muncul ditengah kawasan padat penduduk.

“.... keberpihakannya bukan menjadi bagian lukisan indah Monalisa". Merupakan analogi kedua yang digambarkan dalam karya ini. Lukisan Monalisa yang umumnya ditanggapi dengan rasa sensasi dari keindahan pada dasarnya menyimpan misteri dibalik senyum indahnya. Dengan kata lain gambaran kondisi sosial yang muncul ke permukaan dalam amatan peneliti masih menyimpan misteri, terutama jika kita mengamati pola kesenjangan sosial yang muncul di tengah interaksi masyarakat kawasan Cicadas. Secara sosiologis, munculnya praktik premanisme merupakan efek dari kesenjangan yang terjadi dalam struktur masyarakat. Kesenjangan yang terjadi dapat diakibatkan oleh faktor materi maupun ketidak-sesuaian sebuah kelompok masyarakat dalam struktur sosial. Hal ini pula yang menyebabkan tidak terakomodirnya kepentingan dari salah satu individu atau kelompok dalam struktur masyarakat tertentu. Kesenjangan inilah yang memunculkan semacam protes dan ketidakpuasan dari individual atau kelompok tertentu, sehingga memunculkan praktik-praktik premanisme di tengah masyarakat.

Pandangan terhadap premanisme saat ini tidak dapat diasumsikan demikian. Dalam aspek sosiologis, maraknya praktik premanisme di dalam stuktur masyarakat juga disebabkan oleh faktor struktur sosial dari seorang individu maupun kelompok tertentu. Tindakan premanisme yang terjadi sering diindikasikan sebagai aktivitas dari sekelompok orang yang tidak memiliki pekerjaan. Terjadi pergeseran makna yang mengakibatkan perubahan pada pandangan individual atau kelompok tertentu akan praktek premanisme yang terjadi di perkotaan saat ini. Pada praktiknya, preman yang awalnya memiliki stigma kurang baik di tengah masyarakat memiliki perannya sendiri, termasuk menjaga stabilitas lingkungannya.

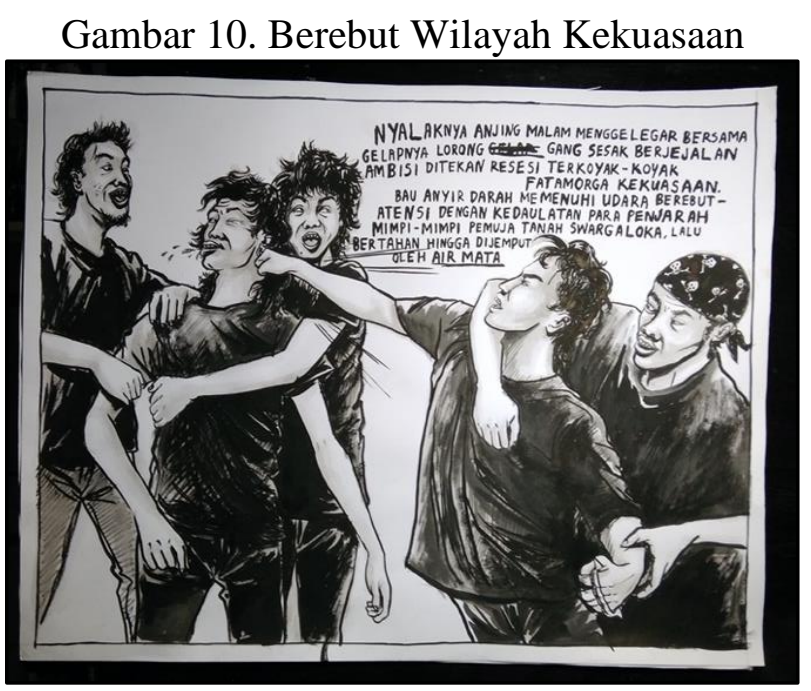

Sumber: dokumentasi peneliti

Teks yang muncul dalam karya ini adalah analogi pada sekelompok masyarakat yang memiliki konotasi negatif. Peneliti mencoba mesuk ke dalam kajian perihal pembagian wilayah administratif paling kecil di Republik Indonesia. Kelurahan dan desa merupakan wilayah administratif tingkat akhir dalam pembagian wilayah di Republik Indonesia. Lazimnya wilayah tersebut dipimpin oleh seorang lurah atau kepala desa. Di sisi lain, ada kelompok-kelompok 
kecil yang merasa secara inisiatif memiliki kekuasaan di wilayah-wilayah tertentu. Hal tersebut yang kerap kali meuncul dari penceritaan yang didapat oleh peneliti saat mengamati kawasan Cicadas. Pembagian wilayah secara sepihak merujuk pada pembagian kawasan wilayah mata pencaharian. Dalam tingkatan jenis pekerjaan yang muncul di kawasan Cicadas, beberapa kelompok masyarakat memilih untuk bekerja secara serabutan, mengandalkan pekerjaan harian yang tidak jarang membuat mereka harus merasakan masa tunggu kala pekerjaan tersebut tak kunjung datang. Masa transisi ini yang menggerakkan inisiatif untuk membentuk kelompokkelompok kecil dalam tatanan masyarakat. Berangkat dari kelompok kecil tersebut, tidak jarang muncul konflik yang berawal dari praktik kepentingan masing-masing kelompok. Cicadas yang merupakan salah satu kawasan padat penduduk dengan berbagai interaksi sosial yang terdapat di dalamnya, memungkinkan praktik-paktik premanisme dalam bingkai yang baru muncul ke permukaan. Hal ini merupakan efek dari gesekan yang terjadi dalam struktur masyarakat di dalamnya. Pada dasarnya praktik tersebut muncul akibat gejala-gejala sosial yang terdapat di dalam lingkungan sosial, namun tidak jarang praktik premanisme menjadi pilihan hidup beberapa individu maupun kelompok masyarakat.

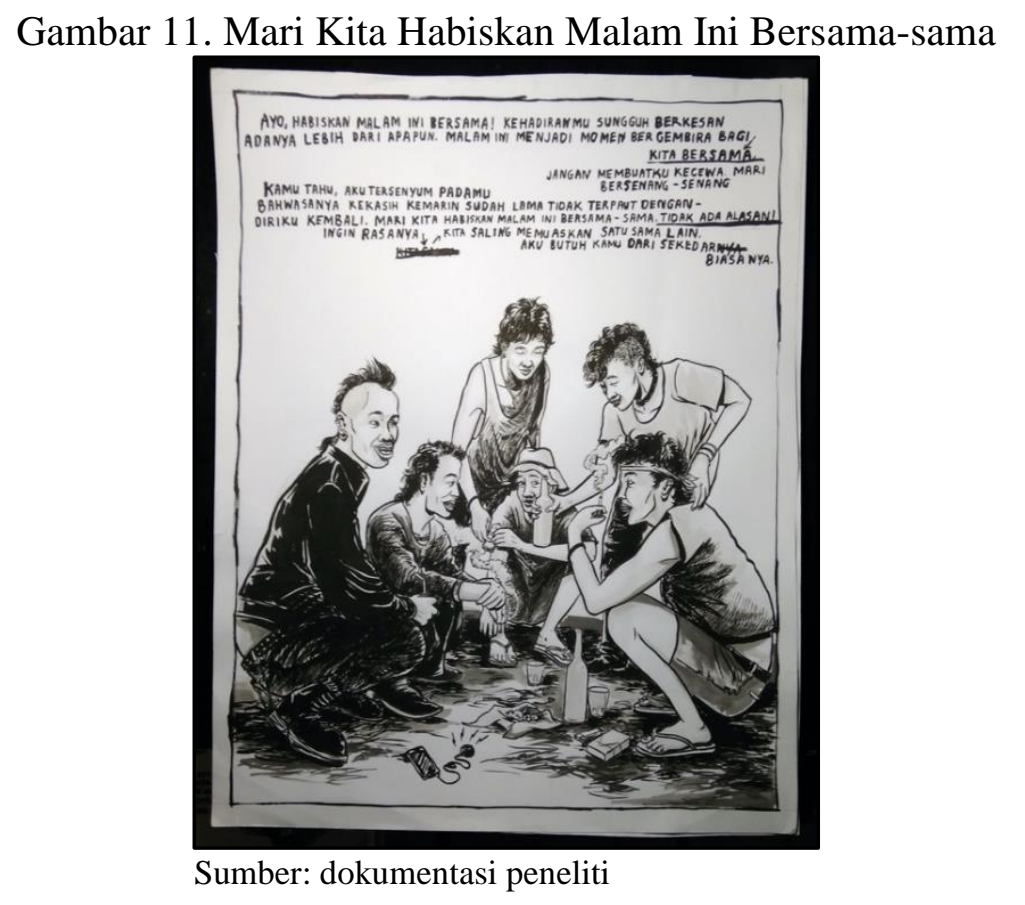

Pengamatan yang dilakukan oleh peneliti berlangsung di tengah pandemi Covid-19. Hal tersebut merupakan tantangan tersendiri, mengingat sulitnya memperoleh akses untuk dapat secara langsung terjun ke lapangan dalam upaya mengamati perilaku sosial yang muncul di tengah masyarakat. Secara etika, pengamatan yang dilakukan oleh peneliti terkesan sedikit memaksakan, namun peneliti merasa perlu terjun secara langsung untuk melihat kondisi sosial di tengah masyarakat kawasan Cicadas.

Sejauh pengalaman yang diperoleh dari kawasan Cicadas, budaya berkumpul sangat kental terbentuk sejak lama. Jika kita menilik kondisi di kawasan padat penduduk, hampir tidak mungkin rasanya untuk menghentikan kebiasaan masyarakat di dalamnya supaya mengurangi kebiasaan berkumpul. Realitas sosial yang terbentuk dalam tatanan masyarakat seolah-olah 
membuat proses berkumpul menjadi peristiwa penting yang mempertemukan beragam gagasan dari setiap individu di dalamnya. Tidak jarang aktivitas ini juga malah menimbulkan gejala sosial yang tidak sesuai dengan ekspektasi masyarakat pada umumnya. Analogi yang digambarkan dalam karya ini tidak jauh berbeda dengan karya "Main Kartu Domino di Pos Kamling Dekat Makam", kebutuhan akan ruang publik sebagai sarana pertemuan masih menjadi faktor yang mendominasi keinginan masyarakat di kawasan Cicadas untuk berkumpul dan menghabiskan waktu.

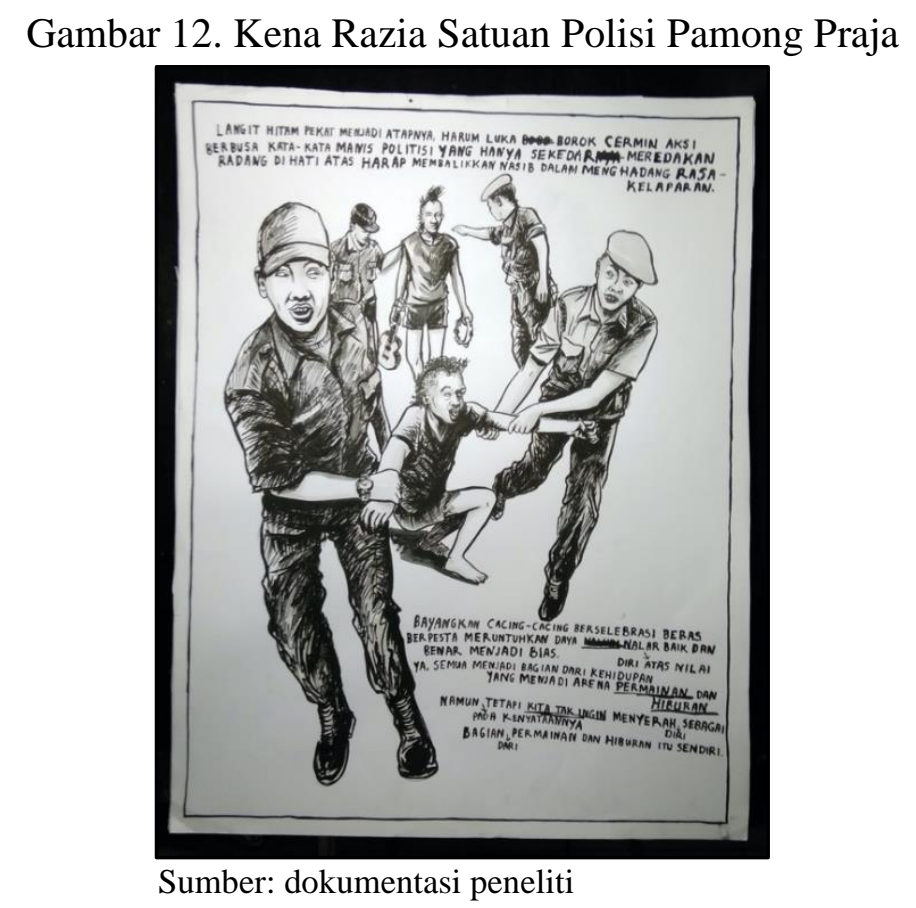

Karya terakhir ini menganalogikan ketakutan akan struktur nilai dan tatanan hukum yang berlaku. Bentuk-bentuk ketimpangan sosial yang muncul di tengah masyarakat kawasan padat penduduk seringkali diselesaikan dengan cara-cara instan. Proses menghukum kadang kala menjadi pilihan utama sebagai bentuk pemberian efek jera pada individu yang melanggar tatanan hukum dan norma. Namun tidak ada tindak lanjut yang merujuk pada perbaikan secara kongkrit dapi para pemangku kebijakan. Sehingga tidak heran jika efek jera yang diberikan selalu bertabrakan dengan praktik kepentingan akan pemenuhan kebutuhan dasar, seperti materi dan alasan kebutuhan primer lainnya.

\section{Simpulan}

Dalam konteks komunikasi seni pada penciptaan karya yang dilakukan oleh Mufty Priyanka, persepsi diasumsikan sebagai inti dari komunikasi yang berlangsung dalam penyampaian pesan dalam karya-karya yg lahir. Ada kalanya persepsi yang muncul tidak akurat, namun tidak dapat disimpulkan bahwa proses komunikasi dalam upaya penyampaian pesan yang terjadi tidak efektif. Persepsilah yang menentukan kita memilih suatu pesan dan mengabaikan pesan yang lain. Semakin tinggi derajat kesamaan persepsi antarindividu, semakin mudah dan semakin sering mereka berkomunikasi dan membentuk identitas dari masing-masing pemaknaan yang muncul. Persepsi akan karya yang berangkat dari representasi 
Mufty Priyanka pada kawasan Cicadas Kota Bandung meliputi sensasi melalui alat-alat indra, atensi dan interpretasi dari setiap penikmat karyanya. Sensasi merujuk kepada pesan yang dikirimkan peneliti melalui penggambaran karya-karyanya. Karya seni Mufty Priyanka mengajak kita untuk merespon berbagai isu terkait gejala serta interaksi sosial yang muncul di kawasan padat penduduk, atau kawasan yang muncul di tengah hiruk-pikuk masyarakat perkotaan. Bisa saja kita gagal mempersepsikan perbedaan yang samar dalam objek yang muncul. Oleh karena itu dalam karya-karyanya, Mufty Priyanka menambahkan teks dengan gaya puitis yang sesuai dengan kecenderungan proses berkarya. Tidak jarang kita melihat kekeliruan ejaan yang terdapat dalam teks pada karya-karya penciptaan ini, namun hal tersebut merupakan upaya yang dilakukan Mufty Priyanka untuk mengajak penikmatnya melakukan konstruksi pemahaman berdasarkan persepsi yang muncul dari stimulus yang diperoleh.

\section{Referensi}

Arkandito, G. F., Maryani, E., Rahmawan, D., \& Wirakusumah, K. (2016). Jurnal manajemen komunikasi. 1(1), 42-56.

Darmawan, H. (2016). Pembelajaran Berbasis Konstruktivisme Menggunakan Media Animasi dengan Kerangka Kerja TPCK dan Gaya Belajar Terhadap Prestasi Belajar Siswa. Formatif: Jurnal Ilmiah Pendidikan MIPA, 6(1), 1-11. https://doi.org/10.30998/formatif.v6i1.747

Dewey, J. (1980). Art as Experience. https://doi.org/10.7208/chicago/9780226247212.003.0006

Gilbert, A., \& Gugler, J. (1996). Urbanisasi dan Kemiskinan di Dunia Ketiga. Yogyakarta: Tiara Wacana.

Gombrich, E. H. (2000). Art and Illusion: A Study in the Psychology of Pictorial Representation (Bollingen) (Revised Ed). Princeton University Press.

Inskip, C., MacFarlane, A., \& Rafferty, P. (2008). Meaning, communication, music: Towards a revised communication model. In Journal of Documentation (Vol. 64). https://doi.org/10.1108/00220410810899718

Jamaludin, A. N. (2015). Sosiologi Perkotaan Memahami Masyarakat Kota dan Problematikanya. In Sosiologi Perkotaan (Mei 2017, Vol. 2). bandung: CV Pustaka Setia Bandung.

Johnson, M. (2007). The Meaning of the Body: Aesthetics of Human Understanding. https://doi.org/10.1163/18758185-90000100

Kamarusdiana, K. (2019). Studi Etnografi Dalam Kerangka Masyarakat Dan Budaya. SALAM: Jurnal Sosial Dan Budaya Syar-I, 6(2), 113-128. https://doi.org/10.15408/sjsbs.v6i2.10975

Kunto, H. (1985). Wajah Bandoeng Tempo Doeloe. Bandung: P.T. Granesia.

Kusuma, A. (2016). Pengantar Komunikasi Antar Budaya. CHANNEL: Jurnal Komunikasi.

Listyana, H. (2015). Persepsi dan Sikap Masyarakat Terhadap Penanggalan Jawa dalam Penentuan Waktu Pernikahan. AGASTYA, 151(1), 10-17. https://doi.org/10.1145/3132847.3132886

Mappalahere, M. T. (2018). Eksistensi Seni Grafitti Di Kota Makassar (Suatu Kajian Sosiologi Seni Tentang Seni Jalanan Sebagai Fenomena Sosial). Jurnal Imajinasi, 2(2), 18. https://doi.org/10.26858/i.v2i2.9548

Muhammad, N. (2017). Resistensi Masyarakat Urban dan Masyarakat Tradisional dalam Menyikapi Perubahan Sosial. Substantia, 19(2), 149-168.

Mulyana, D. (2001). Ilmu KomunikasiSuatu Pengantar. Bandung: Remaja Rosdakarya.

Nugroho, O. C. (2016). INTERAKSI SIMBOLIK DALAM KOMUNIKASI BUDAYA (Studi 
Analisis Fasilitas Publik Di Kabupaten Ponorogo). Aristo, 3(1), 1. https://doi.org/10.24269/ars.v3i1.7

Ramachandran, V., \& Hirstein, W. (1999). The Science of Art: A Neorological Theory of Aesthetic Experience. Journal of Consciousness Studies, 6(6-7), 15-51.

Redies, C. (2015). Combining universal beauty and cultural context in a unifying model of visual aesthetic experience. Frontiers in Human Neuroscience, 9(APR), 1-20. https://doi.org/10.3389/fnhum.2015.00218

Rengganis, T., \& Tjahjodiningrat, H. (2021). Perancangan Film Dokumenter " Living In The Sunlight "Fakultas Pendidikan Seni dan Desain Documentary Film Design " Living In The Sunlight ." Cinematology, 1(1), 102-115.

Santosa. (2008). Menggagas Komunikasi Musikal dalam Pertunjukan Gamelan. Jurnal Ilmu Komunikasi, 5(1), 65-80.

Sugiharto, B. (2013). Untuk Apa Seni? Seri Buku Humaniora. Jakarta: MATAHARI.

Supiarza, H. Sobarna, C. (2019). "Jamaican Sound Keroncong" Cultural Intermixture Product in the Global Era: A Communication Study on the Spread of Keroncong in the Young Generation of Bandung. Humaniora, 10(1).

Supiarza, H. (2019). Rekonstruksi Musik Keroncong Anak Muda di Kota Bandung (Universitas Padjadjaran). Retrieved from http://repository.unpad.ac.id/frontdoor/index/index/docId/24652

Supiarza, H., \& Sarbeni, I. (2021). Teaching and Learning Music in Digital Era: Creating Keroncong Music for Gen Z Students Through Interpreting Poetry. Harmonia: Journal of Arts Research and Education, 21(1), 123-139.

Turniadi, R. (2017). Public Perception of Art in The Village Stem Kuda Lumping Batindih Rumbio Jaya Distric Kampar. JOM FISIP, 4(1), 1-15.

Undiana, N N. (2018). Seni Dan Media Massa: Pengelolaan Informasi Seni Rupa Dalam Media Baru. ATRAT: Visual Art \& Design Journal, 6(2), 174-183.

Undiana, Nala Nandana, Sarbeni, I., Ardiansyah, A., \& Razan, A. P. (2020). Komunikasi Massa pada Kerja Kuratorial Festival Film Sineas Mahasiswa 2020 di Bandung. 2, 15-29.

Warsono. (2012). Jogja Agropop: Visualitas Seni Rupa dan Identitas Kultural. Universitas Gadjah Mada.

Yunus, P. P. (2020). Komunikasi Ekspresif Estetik Karya Seni. JCommsci - Journal Of Media and Communication Science, 3(2), 70-77. https://doi.org/10.29303/jcommsci.v3i2.77

Zahra, F., Mustaqimmah, N., \& Hendra, M. D. (2020). Kekuatan Media Digital Pada Pembentukan Budaya Populer ( Studi Pada Komunitas Moarmy Pekanbaru ). Jurnal Komunikasi, 2(2), 123-136. 